\title{
HIGH SENSITIVE PCR METHOD FOR DETECTION OF PATHOGENIC Leptospira spp. IN PARAFFIN-EMBEDDED TISSUES
}

\author{
Angel Alberto NODA(1), Islay RODRÍGUEZ(1), Yaindrys RODRÍGUEZ(1), Anamays GOVÍN(2), Carmen FERNÁNDEZ(1) \& Ana Margarita OBREGóN(1)
}

\begin{abstract}
SUMMARY
This study describes the development and application of a new PCR assay for the specific detection of pathogenic leptospires and its comparison with a previously reported PCR protocol. New primers were designed for PCR optimization and evaluation in artificially-infected paraffin-embedded tissues. PCR was then applied to post-mortem, paraffin-embedded samples, followed by amplicon sequencing. The PCR was more efficient than the reported protocol, allowing the amplification of expected DNA fragment from the artificially infected samples and from $44 \%$ of the post-mortem samples. The sequences of PCR amplicons from different patients showed $>99 \%$ homology with pathogenic leptospires DNA sequences. The applicability of a highly sensitive and specific tool to screen histological specimens for the detection of pathogenic Leptospira spp. would facilitate a better assessment of the prevalence and epidemiology of leptospirosis, which constitutes a health problem in many countries.
\end{abstract}

KEYWORDS: Leptospira; PCR; LipL32; Pathology; Diagnosis.

\section{INTRODUCTION}

Leptospirosis is one of the most important zoonotic diseases worldwide. The disease varies from subclinical infection to a severe illness with multi-organ involvement. Because of the variety of clinical symptoms, leptospirosis is often misdiagnosed as influenza, hepatic disease and hemorrhagic fever with renal syndrome or dengue fever, leading to an underestimation of prevalence ${ }^{6}$. The tropical climate, which provides periods of intense rainfall resulting in floods, combined with a dense population living in poverty and poor sanitation conditions are key features which favor the maintenance and spread of leptospirosis ${ }^{7,10}$.

The direct demonstration of pathogenic Leptospira spp. as causative agent is an invaluable tool for the diagnosis of human leptospirosis; however, the current bacteriological methods for the detection of leptospires in clinical specimens such as blood, cerebrospinal fluid, urine and post mortem tissue have some disadvantages for routine use. Despite substantial recent improvements there is no current method that is sufficiently sensitive and specific ${ }^{11}$, mainly in samples from deceased individuals where the diagnosis is based on presumptive stain assays.

The polymerase chain reaction (PCR) is the most commonly used method for detecting leptospires in clinical samples ${ }^{16}$. However, postmortem diagnosis of leptospirosis in paraffin-embedded tissue is much less widely used and PCR based methods have low sensitivity for these types of samples ${ }^{3}$.
The most frequently analyzed material in pathology laboratories is paraffin-embedded tissue; indeed, biological samples preserved in this way constitute a valuable source of information for retrospective analysis ${ }^{17}$. Due to DNA fragmentation during sample processing for paraffin blocks, the PCR must be highly sensitive and specific; therefore, few reliable PCR methods exist currently for the detection of pathogen leptospires. The development of more efficient detection systems would therefore be of benefit in the confirmatory diagnosis and the understanding of the epidemiology of leptospirosis in a susceptible population.

\section{MATERIALS AND METHODS}

Primers amplifying a $115 \mathrm{bp}$ PCR product from 23 S ribosomal DNA were published previously ${ }^{18}$. Partial sequences of genes encoding $23 \mathrm{~S}$ rRNA of pathogenic leptospires were obtained from GenBank (http:// www.ncbi.nlm.nih.gov/) and aligned using Clustal software (www.ebi. ac.uk/clustalw/). The specificity of primers was verified by the software BLAST (http://blast.ncbi.nlm.gov/Blast.cgi). Dimer formation was predicted with OPERON (http://www.operon.com/technical/toolkit. aspx). Other parameters such as melting and annealing temperatures, primer length, GC content and $3^{\prime}$ extreme stability were evaluated using BioEdit software (www.bioedit.com/).

In order to design a new set of primers and using Bioedit software, we aligned sequences corresponding to the gene encoding the major

(1) Department of Bacteriology-Mycology. Institute of Tropical Medicine “Pedro Kourí”. Havana. Cuba. Tel.: 255 3530. E-mail: angelalberto@ ipk.sld.cu

(2) Department of Pathology. Institute of Tropical Medicine "Pedro Kourí". Havana. Cuba.

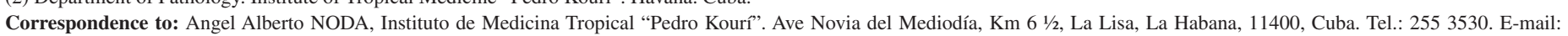
angelalberto@ipk.sld.cu 


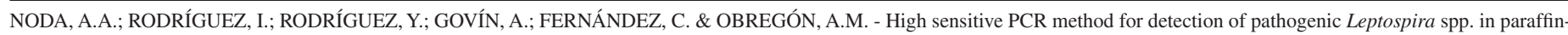
embedded tissues. Rev. Inst. Med. Trop. Sao Paulo, 56(5): 411-5, 2014.

lipoprotein in pathogenic Leptospira spp., lipL32, which is found only in pathogenic strains of Leptospira.

Leptospira borgpetersenii serovar Castellonis strain Castellon 3 was subcultured in EMJH medium for seven days. When cell density had reached approximately $10^{8} \mathrm{cell} / \mathrm{mL}$, the DNA was extracted using High Pure PCR Template Preparation Kit (ROCHE, Switzerland) for genomic DNA. The quality of extracted DNA was checked by spectrophotometry and by agarose gel electrophoresis.

The PCR was performed in a $25 \mu \mathrm{L}$ volumes containing variable concentrations of each primer, $0.125 \mathrm{U}$ of Taq polymerase (QIAGEN, Germany), PCR buffer $1 \mathrm{X}$ (dNTP $0.02 \mathrm{mM}, \mathrm{MgCl}_{2} 0.25 \mathrm{mM}, \mathrm{KCl}$ $0.025 \mathrm{M}$, Tris $\mathrm{HCl} 0.025 \mathrm{M}$, bovine serum albumin $0.1 \mathrm{mg} / \mathrm{mL}$ ), $5 \mu \mathrm{L}$ of template DNA and made up to $25 \mu \mathrm{L}$ with double-distilled water.

The reaction was performed using a Mastercycler personal Eppendorf thermal cycler for 40 cycles. The annealing temperature was chosen from a temperature gradient $\left(53,55,57,59,61\right.$ and $\left.63^{\circ} \mathrm{C}\right)$ with $0.5 \mu \mathrm{M}$ of primer concentration and then, different primers concentrations were used: $0.5 ; 0.2$ and $0.1 \mu \mathrm{M}$. The cycling process involved five steps as follows: 1) $94{ }^{\circ} \mathrm{C}$ for five min, 2) $94{ }^{\circ} \mathrm{C}$ for one min, 3) optimal annealing temperature for $30 \mathrm{sec}, 4$ ) extension at $72{ }^{\circ} \mathrm{C}$ for one min, and a final cooling step of $4{ }^{\circ} \mathrm{C}$. A total of $20 \mu \mathrm{L}$ of the PCR products was analyzed on a $2 \%$ agarose gel and visualized with ethidium bromide staining under ultraviolet light.

Serial and ten-fold dilutions of serovar Castellonis DNA were made from $7 \times 10^{7} \mathrm{geq} /$ reaction to $0.7 \mathrm{geq} /$ reaction for estimating the PCR detection limit. In addition, DNA extracted from related strains (L. interrogans serovar Copenhageni (M20), L. interrogans serovar Icterohaemorrhagiae (RGA), L. interrogans serovar Pomona (Pomona), L. interrogans serovar Canicola (Hond Utrecht IV), L. interrogans serovar Hardjo (Hardjoprajitno), L. interrogans serovar Pyrogenes (Salinem), L. kirschneri serovar Gryppotiphosa (Moskva V), L. interrogans serovar Autumnalis (Akiyami A), L. kirschneri serovar Cynopteri (3522 C)) and unrelated species (L. biflexa serovar Patoc (Patoc I), Borrelia burgdorferi sensu stricto B31, B. garinii NE83, B. afzelii NE17, Mycoplasma genitalium ATCC 33530, Haemophilus influenzae type b ATCC 49629, Streptococcus pneumoniae ATCC 49619, S. agalactiae ATCC 13813, Pseudomonas aeuruginosa ATCC 27853, Escherichia coli ATCC 35218, and $E$. coli ATCC 25922), were used for the specificity assay. Results from the PCR sensitivity and specificity tests were compared with 23S-based PCR (23S PCR) results, according to the WOO et al. (1997) procedure ${ }^{18}$.

The new PCR method (LipL32 PCR) in paraffin-embedded tissues was compared with the 23S PCR. First, paraffin-embedded human tissues negative for leptospirosis by Haematoxilin-Eosin and Warthin-Starry stains were evaluated. Fragments of liver, lung and kidney samples were cut into small pieces (approximately $5 \mathrm{~g}$ ) and inoculated with $100 \mu \mathrm{L}$ of a bacterial suspension (approximately $10^{7} \mathrm{cell} / \mathrm{mL}$ ) and other bacterial species as described above using a syringe. Two pieces of inoculated and non-inoculated (negative control) tissues were immediately paraffinembedded; finally they were used directly for DNA extraction.

Fifty seven paraffin-embedded organ samples (liver, kidney, lung, brain, heart or spleen) from 24 dead patients with suspicion of leptospirosis, received at the National Reference Laboratory of
Leptospires (IPK) during 2012, were tested firstly by a PCR method detecting sample inhibition and this amplified a $268 \mathrm{bp}$ of the gene encoding human $\beta$-globin ${ }^{15}$; after, the non-inhibited samples were subjected to the application of both PCR methods, LipL32 PCR and 23S PCR.

The DNA extraction was performed with Chelex-100 as described by DE ARMAS et al. (2006) ${ }^{5}$ with minor modifications. Briefly, $10 \mu \mathrm{m}$ fragments of paraffin-embedded tissue (cut previously using microtome) were thinly cut with scalpel and put into a $1.5 \mathrm{~mL}$ tube containing 200 $\mu \mathrm{L}$ of $5 \%$ Chelex-100 solution in Tris-EDTA $1 \mathrm{X}$; then it was vortexed and heated to $95{ }^{\circ} \mathrm{C}$ during $15 \mathrm{~min}$, followed by a $13000 \mathrm{xg}$ spin for $10 \mathrm{~min}$. Finally, $5 \mu \mathrm{L}$ of supernatant containing the DNA was used as template for PCR assays.

Ten PCR amplified products from different patients were gelpurified with the QIAEX II (QIAGEN) commercial kit following the manufacturer's instructions. Sequencing of the gel-purified amplicons was performed using the GenomeLabTM Dye Terminator Cycle Sequencing with Quick Start Kit (Beckman Coulter®; USA).

This study was conducted in compliance with the Declaration of Helsinki and it was approved by the Institutional Ethical Committee.

\section{RESULTS}

The complete in silico analysis of $23 \mathrm{~S}$ PCR primers predicted the formation of primer dimers, but the main deficiency was the recognition by BLAST, with $100 \%$ homology, of non-leptospiral bacterial strains; mainly E. coli, Streptococcus suis, S. agalactiae, Yersinia enterocolitica, Pseudomonas aeruginosa, P. mendocina, $P$. basiacearum, Bacillus thuringiensis, B. amyloliquefaciens, Aeromonas veronii, Vibrio cholerae, Brucella melitensis, Clostridium botulinum, C. lentocellum, Leishmania mexicana, Trichomonas vaginalis and Candida parapsilosis. This unexpected result led us to design a new set of primers that fulfilled the requirement for PCR specificity; they define a 146 bp region of DNA unique to pathogenic Leptospira spp. The new primers designated pfLp32-1 and pfLp32-2 have the sequences 5'-TAGAATCAAGATCCCAAATCCTCC-3' and 5'-CCAACAGATGCAACGAAAGATCC-3', respectively.

The annealing temperature gradient assay showed that the best amplification in terms of quantity of PCR product was observed at $59^{\circ} \mathrm{C}$, and it was selected for all further studies. A primer concentration of $0.5 \mu \mathrm{M}$ showed the clearest and most prominent PCR product in agarose gel electrophoresis; this was used, for all subsequent experiments. The detection limit assay of LipL32 PCR showed amplification down to a dilution corresponding to $7 \mathrm{geq} /$ reaction (Fig. 1). In addition, all the leptospiral strains except for the saprophytic serovar Patoc gave rise to the expected DNA fragment. On the other hand, no bands were observed when the non-leptospiral strains were used for the LipL32 PCR. In contrast, the 23S PCR resulted in non-specific amplification in some cases with non-leptospiral strains as Haemophilus influenzae and Streptococcus pneumoniae, although weak signals were observed in both cases.

When we applied the LipL32 PCR to detect pathogenic Leptospira spp. in fresh tissues that had been inoculated with bacterial suspensions and immediately embedded in paraffin, all of the artificially infected 


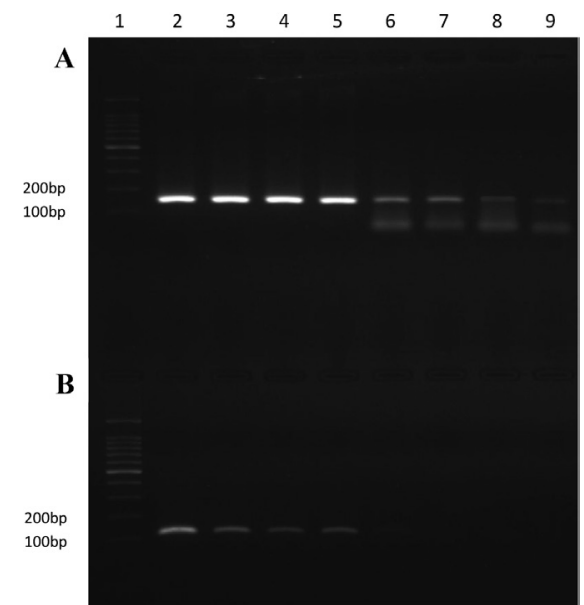

Fig. 1 - PCR amplification from Leptospira borgpetersenii serovar Castellonis strain Castellon 3 DNA dilutions. (A) Using primers pfLp32-1 and pfLp32-2, (B) Using primers of 23S PCR. Lane 1: Molecular weight pattern (100bp PROMEGA); lane 2: DNA 7x107 geq/reaction;

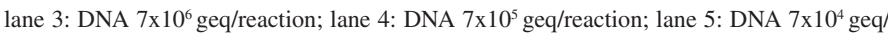

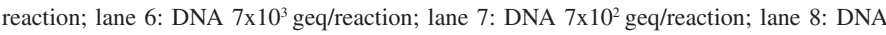
$7 \mathrm{geq} / \mathrm{reaction}$; lane 9: DNA $0.7 \mathrm{geq} /$ reaction.

samples showed the expected amplicon by gel electrophoresis, while no product was observed from the organs artificially infected with nonleptospiral strains. However, with 23S PCR three samples infected with Leptospira were negative and the others were positive but with a lower intensity band; no product was generated from the non-leptospiral strains.

Just two samples from liver and kidney revealed PCR inhibition by human $\beta$-globin PCR; these were not used in further studies. Forty four percent of samples (24/55) from 12 deceased patients with suspected leptospirosis were positive by the LipL32 PCR, while no amplification was observed when 23S PCR was used (Fig. 2). The organs showing the highest intensity of PCR product were kidney (10/18), liver (7/16) and lung (6/9), but with no statistically significant differences between them $(p>0.05)$. In $83 \%(10 / 12)$ of the patients it was noted there was positivity in more than one organ.

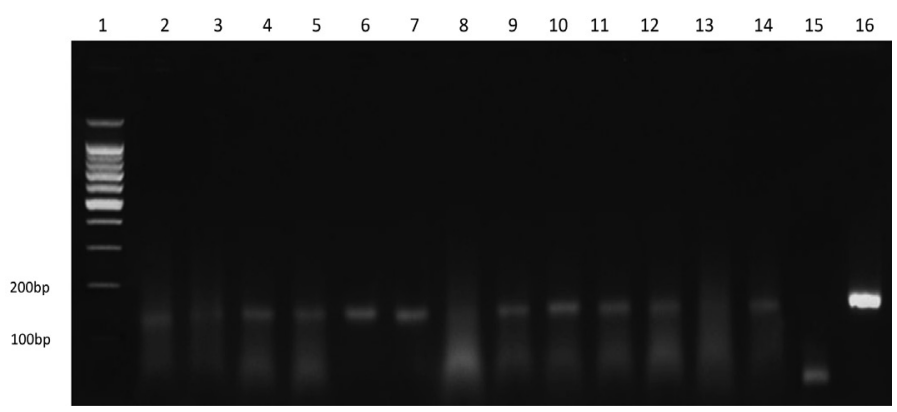

Fig. 2 - PCR amplification showing some positive paraffin-embedded tissue samples from deceased with suspect of leptospirosis. Lane 1: Molecular weight pattern (100bp PROMEGA); lanes 2 to 14: samples; lane 15: negative control ( $\mathrm{H}_{2} \mathrm{O}$ ultrapure); lane 16: positive control (DNA of L. borgpetersenii serovar Castellonis strain Castellon 3).

All sequenced DNA fragments showed $>99 \%$ sequence identity to the pathogenic Leptospira spp. lipL32 gene fragment in GenBank, confirming the amplification specificity of the pfLp32-1 and pfLp32-2 primers.

\section{DISCUSSION}

In this study, we designed and validated a PCR strategy for the detection of pathogenic leptospires in paraffin-embedded organs. PCR analysis of such specimens is hindered by fastidious specimen due to the possible DNA fragmentation produced during the paraffin fixing process and by the low burden of leptospires, particularly when the analysis is performed on thin paraffin sections and with samples contaminated by other microorganisms ${ }^{19}$. In these cases, it is necessary to have a highly sensitive and specific PCR method, capable of amplifying a small DNA region.

The primers reported for use in the $23 \mathrm{~S}$ PCR are not suitable for a highly specific PCR due to the fact that they theoretically recognized, with $100 \%$ match, a wide group of microorganisms not belonging to the genus Leptospira. This lack of specificity presents a major problem, since several species of microorganisms could be present in organ fragments and unexpected amplification can appear. In contrast, the LipL32 PCR was highly specific for pathogenic leptospires. According to results obtained with respect to specificity assay for $23 \mathrm{~S}$ PCR, the in silico results for non-leptospiral strains (except to Haemophilus influenzae and Streptococcus pneumoniae where weak and unspecific bands appeared) were different from the empirical results. This could be explained by genetic differences among the experimentally used bacterial strains and those whose DNA sequences appear in GenBank database. Besides, it is necessary to have the same recognizing pattern by both primers to target DNA, in order to assure a specific amplification.

What was remarkable in the sensitivity assay with LipL32 primers (Fig. 1, panel A) was the fact that free primers start to appear when the template concentration is lower and less product is amplified. However, Panel B did not show any band of free primers, which suggested that the $23 \mathrm{~S}$ primer concentration was insufficient for optimal amplification, and this could have affected the PCR sensitivity. But given the unsatisfactory in silico evaluation performance of primers, we decided not to optimize parameters in the PCR.

Successful performance evaluation of LipL32 PCR in artificially infected tissues demonstrated the usefulness of this assay when tissues were used as matrix. In addition, during the artificial infection procedure, $10^{7} \mathrm{cell} / \mathrm{mL}$ was used in order to ensure efficiency of the process, in spite of the low leptospiral burden probably founded in post-mortem samples.

The successful PCR amplification with paraffin-embedded samples supports for the first time the use of Chelex-100 for the DNA extraction from leptospires in this kind of sample. Chelex-100 has an increased affinity for heavy metal cations such as $\mathrm{Ca}^{2+}, \mathrm{Mn}^{2+}$ and $\mathrm{Mg}^{2+}$. It is known that the divalent metals can introduce DNA damage at a high temperature (e.g. $100^{\circ} \mathrm{C}$ ), and in the case of $\mathrm{Mg}^{2+}$, it is necessary for nuclease activity. Therefore, the use of Chelex-100 inactivates the nucleases and removes the divalent metals and some other PCR inhibitors ${ }^{1}$. The use of an internal control has allowed the demonstration of the high performance of Chelex-100 extraction method in these samples, with only a $3.5 \%$ of inhibited reactions.

The positive LipL32 PCR for the paraffin-embedded tissues and the identification of the amplicon as a lipL32 gene fragment of $L$. interrogans confirmed the etiological cause of death for the patients 
NODA, A.A.; RODRÍGUEZ, I.; RODRÍGUEZ, Y.; GOVÍN, A.; FERNÁNDEZ, C. \& OBREGÓN, A.M. - High sensitive PCR method for detection of pathogenic Leptospira spp. in paraffinembedded tissues. Rev. Inst. Med. Trop. Sao Paulo, 56(5): 411-5, 2014.

studied. The deficiency of the 23S PCR for the detection of DNA of pathogenic leptospires was also demonstrated; however, D'ANDREA et al. (2012) validated this assay in paraffin-embedded tissue with encouraging results ${ }^{4}$. Hence, a highly sensitive and specific PCR constitutes a valuable alternative for the leptospirosis confirmation in fatal human cases, in which a positive serological result is absent, because of either the lack of a serum sample or a significant level of antibodies.

Leptospirosis causes damage to capillary endothelial cells as the underlying cause of clinical manifestations, such as renal tubular dysfunction, liver disease, myocarditis and pulmonary hemorrhage ${ }^{9}$. The fact of finding higher positivity rates in kidney, liver and lung samples was consistent with this notion. A similar observation was reported in a recent molecular study using fresh tissues ${ }^{12}$. The positivity found in the lung samples supports the results reported by other authors on the potentially fatal damage to this organ during leptospiral infection ${ }^{8,13,14}$. The positivity was found in more than one organ per patient which suggests multi-organ infection. Unfortunately, clinical-epidemiological information from the deceased was incomplete; thus we could not make any inference of the founded positivity with multiorgan failure.

Paraffin-embedded tissue blocks are routinely used for histopathological examination and are also useful for specific pathogen detection by PCR. Paraffin-embedded tissue is stable at ambient temperature for an extended period of time and relatively easy to transport compared to fresh tissue, which has to be processed or frozen immediately ${ }^{2}$. In addition, archival material is an invaluable source for retrospective molecular and clinical investigation; nevertheless, fresh tissue samples are the specimens of relevance for prevalence and epidemiological studies for leptospirosis, consequently this kind of sample would be also evaluated using the proposed PCR.

As a final point, the detection of DNA from paraffin-embedded specimens by PCR is important for the retrospective study of different infectious diseases, including their epidemiology and risk assessment. This is particularly important for leptospirosis, due to the variety of clinical symptoms and signs, potentially leading to misdiagnosis and underestimation of disease prevalence worldwide.

\section{RESUMEN}

\section{PCR altamente sensible para la detección de Leptospira spp. patógenas en tejidos embebidos en parafina}

El presente estudio describe el desarrollo y aplicación de un nuevo ensayo de PCR para la detección específica de leptospiras patógenas y su comparación con un protocolo reportado previamente. Se diseñaron nuevos cebadores para la optimización y evaluación de la PCR en tejidos embebidos en parafina infectados artificialmente. La PCR se aplicó además a muestras de tejidos embebidos en parafina y se realizó la secuenciación del amplicón resultante. La PCR diseñada fue más eficiente que el protocolo reportado, permitiendo la amplificación del fragmento de ADN esperado en las muestras infectadas artificialmente y del $44 \%$ de las muestras post mortem. Se secuenciaron 10 amplicones provenientes de pacientes diferentes. La aplicabilidad de una herramienta altamente sensible y específica en la búsqueda de leptospiras patógenas en especímenes histopatológicos podría facilitar una mejor valoración de la prevalencia y la epidemiología de la leptospirosis, la que constituye un problema de salud en disímiles países.

\section{CONFLICT OF INTEREST}

The authors declare that they have no conflict of interest.

\section{ACKNOWLEDGEMENTS}

We would like to acknowledge Prof. Virginia Capó, for her attention and suggestions, to Prof. Ben Adler and Prof. James Matsunaga, for the critical revision of the manuscript.

\section{REFERENCES}

1. Aygan A. Nucleic acid extraction from clinical specimens for PCR applications. Turk J Biol. 2006;30:107-20.

2. Behrhof W, Springer E, Bräuninger W, Kirkpatrick CJ, Weber A. PCR testing for Treponema pallidum in paraffin-embedded skin biopsy specimens: test design and impact on the diagnosis of syphilis. J Clin Pathol. 2008;61:390-5.

3. Brown PD, Carrington DG, Gravekamp C, van de Kemp H, Edwards CN, Jones SR, et al. Direct detection of leptospiral material in human postmortem samples. Res Microbiol. 2003;154:581-6.

4. D’Andrea A, Zamora Y, Alduina R, Monteverde V, Fernández C, Vitale M. Comparison of two PCR methods for detection of Leptospira interrogans in formalin-fixed and paraffin-embedded tissues. Mem Inst Oswaldo Cruz. 2012;107:85-8.

5. De Armas Y, Capó V, González E, Mederos L, Díaz R. DNA extraction from paraffin embedded tissues by Chelex-100. Rev Esp Patol. 2006;39:171-4.

6. Evangelista KV, Coburn J. Leptospira as an emerging pathogen: a review of its biology, pathogenesis and host immune responses. Future Microbiol. 2010;5:1413-25.

7. Fonseca CA, Freitas VLT, Romero EC, Spinosa C, Arroyo Sanches MC, Da Silva MV, et al. Polymerase chain reaction in comparison with serological tests for early diagnosis of human leptospirosis. Trop Med Int Health. 2006;11:1699-707.

8. Gouveia EL, Metcalfe J, de Carvalho AL, Aires TS, Villasboas-Bisneto JC, Queirroz A, et al. Leptospirosis associated Severe Pulmonary Hemorrhagic Syndrome, Salvador, Brazil. Emerg Infect Dis. 2008;14:505-8.

9. Hill MK, Sanders CV. Leptospiral pneumonia. Semin Respir Infect. 1997;12:44-9.

10. Ko AI, Galvão RM, Ribeiro Dourado CM, Johnson WD Jr, Riley LW. Urban epidemic of severe leptospirosis in Brazil. Salvador Lystospirosis Study Group. Lancet. 1999;354(9181):820-5.

11. Rodríguez I, Rodríguez I, Fernández C, Rodríguez JE, Cantillo J. Detection of leptospires from infected urine and tissue samples in vitro by modified Fontana silver stain. J Bras Patol Med Lab. 2013a;49:43-9.

12. Rodríguez Y, Rodríguez I, Zamora Y, Rodríguez JE, Valdés Y, Echevarria E, et al. Detección de ADN de leptospiras en tejidos frescos de fallecidos en Cuba, 2008-2011. Rev Cubana Med Trop. 2013b;65:211-22.

13. Santos Pérez LA, Bilbao González K, Segredo Molina Y, Cartaya Irastorga JM. Leptospirosis grave asociada con hemorragia pulmonar. Presentación de 3 pacientes pediátricos UCIP. Hospital Universitario “José Luis Miranda”. Rev Panam Infectol. 2008; $10: 36-42$.

14. Seijo A, Coto H, San Juan J, Videla J, Deodato B, Cernigoi B, et al. Lethal leptospiral pulmonary hemorrhage: an emerging disease in Buenos Aires, Argentina. Emerg Infect Dis. 2002;8:1004-5. 
NODA, A.A.; RODRÍGUEZ, I.; RODRÍGUEZ, Y.; GOVÍN, A.; FERNÁNDEZ, C. \& OBREGÓN, A.M. - High sensitive PCR method for detection of pathogenic Leptospira spp. in paraffinembedded tissues. Rev. Inst. Med. Trop. Sao Paulo, 56(5): 411-5, 2014.

15. Talmaci R, Traeger-Synodinos J, Kanavakis E, Coriu D, Colita D, Gavrila L. Scanning of beta-globin gene for identification of beta-thalassemia mutation in Romanian population. J Cell Mol Med. 2004;8:232-40.

16. Toyokawa T, Ohnishi M, Koizumi N. Diagnosis of acute leptospirosis. Expert Rev Anti Infect Ther. 2011;9:111-21

17. Wiedorn KH, Olert J, Stacy R, Goldmann T, Kühl H, Matthus J. HOPE a new fixing technique enables preservation and extraction of high molecular weight DNA and RNA of $>20 \mathrm{~kb}$ from paraffin-embedded tissues. Herpes-Glutamic acid buffe mediated organic solvent Protection Effect. Pathol Res Pract. 2002;198:735-40.
18. Woo TH, Smythe LD, Symonds ML, Norris MA, Dohnt MF, Patel BK. Rapid distinction between Leptospira interrogans and Leptospira biflexa by PCR amplification of $23 \mathrm{~S}$ ribosomal DNA. FEMS Microbiol Lett. 1997;150:9-18.

19. Wu L, Patten N, Yamashiro CT, Chui B. Extraction and amplification of DNA from formalin-fixed, paraffin-embedded tissues. Appl Immunohistochem Mol Morphol. 2002;10:269-74.

Received: 26 August 2013

Accepted: 12 February 2014 